\title{
EKSISTENSI KESENIAN JEPIN DI DUSUN BANDUNGAN DESA DARMAYASA KECAMATAN PEJAWARAN KABUPATEN BANJARNEGARA
}

\author{
Oleh : Ika Prawita Herawati \\ (Pembimbing Tugas Akhir: Dra. Budi Astuti, M. Hum dan Dra. Daruni, M. Hum) \\ Jurusan Tari Fakultas Seni Pertunjukan, Institut Seni Indonesia Yogyakarta \\ Alamat Email: Ikaprawita.ip@gmail.com
}

\section{RINGKASAN}

Kesenian Jepin merupakan salah satu kesenian rakyat yang masih bertahan hingga sekarang di dusun Bandungan. Eksistensi kesenian tersebut di dusun Bandungan desa Darmayasa disajikan dalam berbagai acara yaitu acara dusun seperti pesta nadar, dan acara hajatan seperti khitanan, dan pernikahan. Selain itu, keseniaan Jepin juga disajikan dalam acara peringatan hari kemerdekaan Republik Indonesia dan penyambutan tamu.

Kesenian Jepin sampai sekarang masih eksis dalam masyarakat dusun Bandungan terbukti dari banyaknya penonton dan frekuensi pertunjukan atau banyaknya tawaran pentas. Kesenian ini memiliki fungsi yang penting yaitu sebagai hiburan. Sejak awal terbentuknya hingga sekarang, kesenian ini telah mengalami perkembangan baik dari gerak dan penambahan alat musik. Hal tersebut merupakan salah satu upaya untuk mempertahankan keberadaan kesenian Jepin agar dapat bertahan, tetap eksis dan diminati oleh masyarakat.

Masyarakat dusun Bandungan merasa bahwa mereka membutuhkan kesenian Jepin sebagai hiburan dan sebagai bagian dari budaya yang patut dibanggakan. Kesenian Jepin dapat bertahan sampai sekarang menunjukan bahwa kesenian ini mempunyai kedudukan dalam masyarakat dusun Bandungan. Tanggapan yang baik dari masyarakat ditunjukkan pula dengan semakin menyebar luasnya kesenian Jepin di berbagai daerah di kecamatan Pejawaran dan sekitarnya.

Kesenian Jepin tetap bertahan dan diminati oleh masyarakat serta eksis juga karena kesenian ini sejalan dengan adat-istiadat yang berlaku dalam masyarakat dusun Bandungan.
\end{abstract}

\section{Kata Kunci : Eksistensi, Jepin, Bandungan.}




\begin{abstract}
The art Jepin is one of the folk art that still survive today in the Hemlet Bandungan. The existence of the arts in the Hamlet Bandungan Village Darmayasa served in a variety of activities such as slamatan, in celebration events such as circumcision. Additionally, Jepin also presented in commemoration of the independence of the Republic of Indonesia and welcoming guests.

The art Jepin until now still exist in society Hamlet Bandungan evident from the many spectators and the frequency or the number of bids stage show. This art has an important function, namely as entertainment. Since the beginning of formation until now, this art has been progressing. It is an effort to maintain the existence of Jepin order to survive, still exist and the demand by the public.
\end{abstract}

The existence of this art in the Hamlet Bandungan namely as a means of fostering a sense of unity among the citizens, to tighten friendship and solidarity binding the people in the village. At Hamlet Bandungan community feel that they need Jepin as entertainment and as part of the cultural assets to be proud. Art Jepin can survive up to now shows that this art has no place in society Hamlet Bandungan. Jepin their benefit to society in general and public support for the arts. A good response from the public indicated also by the increasing spread breadth Jepin in various areas in the subdistrict Pejawaran.

Jepin art persisted and demand by the public and also for art to exist, is in line with the customs prevailing in society hamlet Bandungan.

Keywords: existence, Jepin, Bandungan

\section{PENDAHULUAN}

Kesenian Jepin merupakan kesenian yang tergolong kesenian rakyat. Kesenian Jepin dalam pertunjukannya menampilkan gerakan Pencak Silat, tetapi gerakan-gerakan tersebut merupakan gerakan-gerakan olah fisik yang tujuan akhirnya adalah keindahan gerak, bukan lagi bela diri dan kemenangan terhadap lawan. Unsur gerak pada kesenian Jepin yang meliputi sikap gerak tangan dan kaki bersumber pada unsur gerak pencak silat ini terdiri dari dua aspek yaitu gerak tangkisan dan serangan. Kegagahan pada motif pencak silat dapat dilihat dari sikap tubuh, volume gerak, dan pengerahan tenaga. Bentuk-bentuk motif tersebut dikonstruksikan sebagai suatu bentuk ragam tari, meskipun secara visual masih nampak gerak silat. 


\section{JOGED}

ISSN: $1858-3989$
Ika Prawita Herawati (EKSISTENSI KESENIAN JEPIN DI DUSUN BANDUNGAN DESA DARMAYASA KECAMATAN PEJAWARAN KABUPATEN BANJARNEGARA)
Paguyuban kesenian Jepin banyak terbentuk di berbagai daerah di Banjarnegara, terutama pada daerah pegunungan salah satunya di Desa Darmayasa Kecamatan Pejawaran. Desa Darmayasa merupakan daerah agraris yang mayoritas penduduknya memiliki mata pencaharian pada sektor pertanian.

Desa Darmayasa merupakan salah satu desa yang ada di Banjarnegara, yang terletak di Kecamatan Pejawaran. Pejawaran sendiri terletak di bagian Utara Kabupaten Banjarnegara, yang merupakan kawasan pegunungan yang merupakan bagian dari Dataran Tinggi Dieng, Pegunungan Serayu Utara. Desa Darmayasa berada di zona utara, dengan letak geografis Desa Darmayasa berada diantara $7^{\circ} 12^{\prime}-7^{\circ} 31^{\prime}$ Lintang Selatan dan $109^{\circ} 29^{\prime}-109^{\circ} 45^{\prime} 50^{\prime \prime}$ Bujur Timur.

Kecamatan Pejawaran terletak di bagian Utara Kabupaten Banjarnegara, yang merupakan kawasan pegunungan yang merupakan bagian dari Dataran Tinggi Dieng, Pegunungan Serayu Utara. Daerah ini memiliki relief yang curam dan bergelombang. Luas wilayah Desa Darmayasa sekitar 607,24 Ha. Desa Darmayasa mempunyai batas wilayah sebagai berikut:

Sebelah Utara : desa Tlahab

Sebelah Selatan : desa Karekan

(kecamatan Pagentan)

Sebelah Timur : desa Pejawaran

Sebelah Barat : desa Biting
Banyaknya paguyuban yang terdapat di Pejawaran, Dusun Bandungan Desa Darmayasa merupakan salah satu dusun yang mempunyai satu paguyuban Jepin. Paguyuban ini sudah cukup lama terbentuk dan mampu bertahan hingga sekarang serta tetap diminati oleh masyarakat. Tidak dipungkiri bahwa kesenian ini telah mengalami perkembangan dari awal terbentuknya sampai sekarang. Hal tersebut merupakan upaya untuk mempertahankan keberadaan kesenian Jepin agar tetap eksis dan diminati oleh masyarakat. Paguyuban ini juga tidak menutup diri terhadap masyarakat yang menyampaikan kritik dan saran agar dapat lebih baik lagi dalam menampilkan pertunjukan ke depannya.

Selain itu, selera masyarakat juga dipertimbangkan dalam pertunjukan kesenian ini.

Masyarakat Dusun Bandungan membentuk paguyuban dan mengadakan pertunjukan kesenian didasari oleh rasa senang dan cinta terhadap kesenian Jepin. ${ }^{1}$ Oleh karena itu, masyarakat Bandungan yang menjadi penari, pemusik, dan pendukungnya sangat antusias untuk ikut serta dalam pertunjukan kesenian Jepin walaupun sering tidak dibayar. Kesenian Jepin dalam perjalanannya mengalami pasang surut, akan tetapi paguyuban ini mampu menyiasati

1 Wawancara dengan Bapak Warno selaku ketua paguyuban kesenian Jepin Bandungan pada tanggal 7 Agustus 2016 diperbolehkan untuk dikutip. 
permasalahan tersebut sehingga mampu bertahan, tetap eksis dan diminati oleh masyarakat. Bertahannya kesenian tersebut menandakan bahwa kesenian Jepin masih mempunyai tempat dalam masyarakat. Kesenian ini biasanya ditanggap dalam acara hajatan seperti acara pernikahan, dan khitanan. Kesenian Jepin juga dipertunjukkan ketika hari-hari besar seperti 17-an, lebaran dan mengikuti festival-festival kesenian di Banjarnegara.

Kesenian Jepin biasa dipertunjukkan di lapangan atau di pekarangan rumah warga yang luas karena jumlah pemain yang cukup banyak. Selain itu, masyarakat yang tertarik untuk menonton pertunjukan ini juga banyak maka tempat pertunjukan tersebut juga mempertimbangkan dari sisi penonton. Alat musik Jepin yang digunakan yaitu 3 buah terbang, 1 jidur, dan 1 peluit.

Kesenian Jepin berfungsi sebagai hiburan untuk masyarakat tanpa memungut bayaran. Namun demikian, untuk sekedar melangsungkan hidupnya, setiap orang yang menyelenggarakan pertunjukan kesenian tersebut diharap memberi sokongan sekadarnya. Keberadaan paguyuban Jepin di desa Darmayasa, sejak awal terbentuknya hingga saat ini merupakan salah satu bukti bahwa kesenian Jepin tetap diminati oleh masyarakat dan pendukung keseniannya. Klarifikasi tentang keberadaan tari tak akan pernah tuntas tanpa mengikutsertakan aspekaspek sosiologisnya. ${ }^{2}$ Aspek-aspek sosiologis yang dimaksud yaitu masyarakat dan kehidupan sosial yang terkait dalam kehidupan masyarakat tersebut.

Keterkaitan antara kesenian rakyat dengan masyarakat pendukungnya terjadi pada kesenian Jepin. Peranan dan keberadaan kesenian rakyat dipengaruhi oleh kondisi, kualitas serta respons dari masyarakat sosial di mana kesenian tersebut tumbuh dan berkembang. Keberadaan Kesenian Jepin muncul sebagai warisan leluhur yang secara turun temurun diwariskan kepada generasi selanjutnya.

Kesenian Jepin merupakan sebuah pertunjukan kesenian rakyat yang diminati banyak orang di manapun tempat pertunjukannya berlangsung terbukti pada saat pertunjukan berlangsung masyarakat memenuhi area penonton dan berdesakdesakan untuk bisa melihat pertunjukan kesenian ini. Kesenian Jepin tetap diminati banyak orang terbukti juga dari banyaknya tawaran pentas yang diterima di berbagai acara. Selain itu, ketika kesenian ini berlangsung pada setiap acara, banyak masyarakat yang berdatangan dari berbagai daerah dan pada umumnya bertahan sampai pertunjukan kesenian ini selesai. Kesenian Jepin yang merupakan kesenian rakyat dengan

2 Y. Sumandiyo Hadi, 2005, Sosiologi Tari: Sebuah Pengenalan Awal, Pustaka, Yogyakarta, 30. 


\section{JOGED}

ISSN: $1858-3989$
Ika Prawita Herawati (EKSISTENSI KESENIAN JEPIN DI DUSUN BANDUNGAN DESA DARMAYASA KECAMATAN PEJAWARAN KABUPATEN BANJARNEGARA) segala bentuk pertunjukannya mampu bertahan sehingga kesenian ini tetap dapat eksis dan diminati oleh masyarakat di dusun Bandungan.

Dari pengamatan yang telah dilakukan serta penjelasan yang telah diutarakan di atas, peneliti tertarik untuk menganalisis mengenai eksistensi kesenian Jepin di Dusun Bandungan terkait dengan masyarakat pendukung. Fenomena yang ada dalam kehidupan sosial paguyuban kesenian Jepin ini adalah keberadaan dan kemampuan paguyuban kesenian Jepin untuk tetap hidup dan mempertahankan kesenian rakyat.

\section{PEMBAHASAN}

\section{A. Penyajian Kesenian Jepin}

Secara keseluruhan kesenian Jepin mempunyai pembagian dalam penyajiannya. Penyajian kesenian Jepin ini dapat dibagi menjadi tiga bagian, yaitu bagian awal, bagian tengah, dan bagian akhir.

\section{a. Bagian Awal}

Bagian awal atau pembukaan yang berupa masuknya penari ke tengah arena pementasan. Dengan masuknya penari ke arena pementasan pada bagian awal ini paling tidak dapat memberikan gambaran kepada para penonon bahwa pertunjukan kesenian Jepin akan segera dimulai.

b. Bagian Pokok

Bagian pokok merupakan kelanjutan dari bagian awal, pada bagian ini ditampilkan gerak-gerak kesenian Jepin secara berurutan, hingga pada akhirnya masuk pada adegan trance. Para penari dalam keadaan antara sadar dan tidak. Keadaan tidak sadar yang dimaksud di sini, bahwa penari yang berada dalam keadaan trance dapat mengeluarkan kekuatan yang berlebihan dan tidak dimiliki orang dalam keadaan normal. Dikatakan sadar karena dalam keadaan trance mereka masih memiliki pendengaran dan pengertian, apabila sewaku-waktu diberi peringatan dengan bunyi peluit yang biasa dipakai untuk member aba-aba selama pertunjukan berlangsung.

\section{c. Bagian Akhir}

Merupakan bagian terakhir dari kesenian Jepin, pada pertunjukan kesenian Jepin ditandai dengan keluarnya para penari dari arena pertunjukan, dengan keluarnya para penari ini maka selesai juga pertunjukan kesenian Jepin.

Bahan baku tari adalah gerak tubuh, yang setiap orang melakukannya setiap hari. Perbedaan antara gerak dalam tari dan gerak sehari-hari yaitu gerakan dalam tari sudah mengalami pengembangan dan mengandung unsur estetis, sedangkan gerak sehari-hari tidak mengalami pengembangan atau apa adanya.

Menurut Soedarsono, berdasarkan bentuk geraknya, secara garis besar tari dapat dibagi menjadi dua jenis yaitu tari 
yang representasional dan tari yang non representasional. Tari yang representasional adalah tari yang menggambarkan sesuatu secara jelas, sedangkan tari yang non representasional adalah tari yang tidak menggambarkan sesuatu. Gerak tari yang ada dalam kesenian Jepin, dapat digolongkan ke dalam gerak representasional, karena gerakan-gerakannya dapat menggambarkan sesuatu atau mempunyai makna. Gerakan tersebut misalnya memukul, menendang, menangkis, dan lain sebagainya.

Adapun telah disebutkan sebelumnya bahwa sumber gerak kesenian Jepin adalah dari unsur gerak pencak silat, dalam arti bahwa aspek bentuk dasar meliputi sikap dan gerak tangan maupun kaki mengambil unsur dasar pencak silat. Gerak pencak silat yang tajam, kuat, patah-patah, dan cepat akan tampak pada kesenian Jepin sehingga dari gerakan tersebut akan menimbulkan kesan kuat dan dinamis. Kegagahan dan kekuatan pada motif pencak silat dapat terlihat pada sikap tubuh, volume gerak dan pengerahan tenaga. Bentuk-bentuk motif gerak tersebut dikonstruksikan sebagai suatu bentuk ragam tari, tetapi gerak penak silat secara visual masih bisa dilihat.

Adapun gerak-gerak yang terdapat dalam kesenian Jepin antara lain:

1. Kuda-kuda
Gerak ini merupakan gerak permulaan sebelum melakukan jurus berikutnya. Keunikan pada gerak kuda-kuda ini adalah kedua telapak kaki digerakan seperti sedang jinjit-jinjit dan badan membungkuk lurus ke depan.

2. Pukulan ganda

Jurus pukulan ganda ini berisi jurus pukulan yang dikombinasi dengan jurus lain misalnya jurus hindaran. Jurus pukulan ganda ini diawali dengan posisi jongkok dan badan tegap. Kedua kaki berfungsi sebagai tumpuan dengan kaki jinjit. Sedangkan kedua tangan mengepal dan bersiap memulai pukulan bergantian.

3. Tangkisan reflek

Jurus tangkisan ini dilakukan dengan cepat dan fokus karena apabila tidak cepat dan fokus diibaratkan kita akan kalah dengan serangan lawan.

4. Sikap ales

Jurus sikap ales merupakan jurus hindaran kombinasi, pada jurus ini menyimbolkan bahwa kita sedang membanting lawan, seperti tangkisan reflek pada gerak ini dituntut ketegasan dan fokus.

\section{Colokan}

Jurus ini merupakan jurus untuk memukul lawan, pada jurus colokan ini dikombinasi dengan jurus tendangan. 


\section{JOGED}

ISSN: $1858-3989$
Ika Prawita Herawati (EKSISTENSI KESENIAN JEPIN DI DUSUN BANDUNGAN DESA DARMAYASA KECAMATAN PEJAWARAN KABUPATEN BANJARNEGARA)

\section{Serangan}

Jurus serangan merupakan jurus yang paling banyak mengeluarkan tenaga. Di dalam jurus ini, semua jurus harus dikeluarkan untuk mengalahkan lawan.

\section{Serangan pukulan}

Jurus serangan pukulan berisi pukulan berulang-ulang, gunanya agar pukulan tersebut menembus jantung lawan sehingga lawan akan lemas. Tidak hanya pukulan di depan dada saja, namun juga memukul bagian wajah lawan.

\section{Tendangan colokan}

Jurus tendangan colokan ini dipakai untuk lawan yang ada di belakangnya. Jurus ini diawali dengan posisi badan jongkok menghadap ke belakang dan posisi kaki menyilang. Jurus ini menjadi jurus pertahanan diri yang paling mudah dipakai.

\section{Bantingan}

Jurus bantingan, merupakan jurus yang digunakan untuk membanting lawan. Gerak ini difokuskan pada gerak ayunan tangan dalam membanting lawan dan kuda-kuda yang kuat.

10. Hindaran

Jurus hindaran digunakan untuk menghindari serangan lawan. Jurus hindaran yang digunakan berupa hindaran dengan posisi merunduk atau duduk.

\section{Tendangan Putar}

Jurus ini untuk melumpuhkan lawan. Tendangan ini memanfaatkan sendi peluru pada bagian paha untuk melakukan serangannya. Jurus ini diawali dengan jongkok terlebih dahulu, karena sebagai usaha untuk mengumpulkan tenaga saat menendang, kemudian meluncurkan tendangan putar dengan poros satu kaki sehingga melawan musuh dari segala arah.

12. Cimandhe

Gerak cimandhe dilakukan dengan volume pengerahan tenaga secara ringan. Gerakan ini difokuskan pada kaki yang berfungsi sebagai tumpuan, di mana kaki digerakkan ke depan dan ke belakang dalam posisi menyilang secara bergantian. Gerakan ini diikuti dengan ayunan kedua tangan di samping muka dan dilakukan seiring dengan gerakan kaki.

\section{Santungan}

Gerak santungan dilakukan dengan kekuatan penuh yang difokuskan pada tumit kaki. Dalam gerakan ini keseimbangan tubuh ditumpu oleh satu kaki, karena kaki yang satu diangkat dengan posisi telapak kaki menghadap ke depan, sedangkan posisi tangan disilangkan di depan dada. Gerak dan posisi ini menunjukkan sifat kekokohan dan kekuatan.

\section{Slorok}

Pada gerak slorok difokuskan pada kedua tangan yang digunakan untuk menumpu berat badan. Volume yang ditimbulkan dari gerak 
slorok ini cukup besar, karena dilakukan dengan posisi terbuka.

\section{Jangkah Satu}

Gerakan jangkah satu dilakukan dengan kekuatan atau tekanan serta difokuskan pada gerak tangan mengepal dengan dihentakkan secara tiba-tiba. Sikap tubuh pada bagian kaki cenderung terbuka dengan sikap badan pada level sedang.

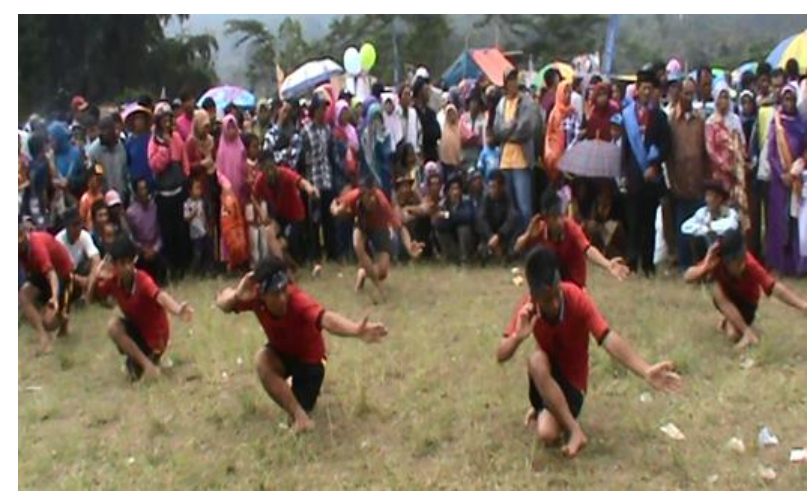

Gambar 1. Penari kesenian Jepin (dok: Ika)

Iringan di dalam tari tidak kalah pentingnya dengan gerak. Iringan digunakan sebagai pengiring tari, pemberi suasana tari, dan sebagai pengantar tari. Sama halnya dengan kesenian Jepin, tari tersebut juga diiringi alat musik sebagai pengiringnya. Dalam penyajian kesenian Jepin digunakan iringan internal dan eksternal. Iringan internal dihasilkan dari para penari yaitu dari suara hentakan kaki dan suara yang dihasilkan oleh tepukan tangan dengan kaki pada waktu melakukan gerakan tangkisan.

\section{Untuk iringan eksternal dihasilkan} dari suara instrumen atau alat-alat musik yang berupa tiga buah terbang dan satu buah jidur.
Jidur yaitu alat musik rakyat semacam terbang atau jidur tetapi dalam ukuran besar, terbuat dari kayu dan membrane dari kulit, dan sebuah peluit yang dipakai salah satu penari, suara peluit berguna untuk mengatur kekompakan gerak penari.

Kesenian Jepin merupakan kesenian rakyat yang berfungsi sebagai hiburan atau tontonan, sehingga tempat pertunjukan bukan merupakan hal yang khusus seperti pada kesenian lain yang berfungsi ritual. Tempat yang digunakan untuk pementasan kesenian Jepin ini bersifat fleksibel, dalam arti dapat dipentaskan di mana saja sesuai dengan kebutuhan. Tempat yang biasa untuk pementasan adalah halaman yang luas atau tanah lapang. Pada beberapa pementasan khusus, seperti pada acara festival, tempat pementasannya berupa panggung. Komposisi pentas yang digunakan dalam setiap pementasan disesuaikan dengan situasi dan kondisi pada saat pementasan.

Untuk penari kesenian Jepin sekitar 10 sampai 20 orang atau tergantung keadaan. Penari dalam kesenian Jepin semuanya adalah laki-laki. Dalam dunia panggung tata rias adalah salah satu sarana penunjang dalam sebuah pertunjukan, baik itu untuk seni fashion show, seni drama, seni tari, ketoprak, maupun dalam pertunjukan wayang orang ${ }^{3}$.

${ }^{3}$ Indah Nuraini, 2011, Tata Rias dan Busana Wayang Orang Gaya Surakarta. BP ISI Yogyakarta, Yogyakarta. 45 


\section{JOGED}

ISSN: $1858-3989$
Ika Prawita Herawati (EKSISTENSI KESENIAN JEPIN DI DUSUN BANDUNGAN DESA DARMAYASA KECAMATAN PEJAWARAN KABUPATEN BANJARNEGARA)
Khususnya dalam hal ini kesenian Jepin. Tata rias yang digunakan oleh para penari adalah rias wajah yang sangat tipis, dalam artian mereka tidak menggunakan riasan panggung seperti kesenian yang lain dan hanya memberikan penekanan pada garis wajah saja seperti alis, kumis dan godheg. Untuk riasan seperti ini bahkan biasanya tidak menggunakan riasan sama sekali, dan hanya menggunakan busana kesenian Jepin.

Untuk tata busana kesenian Jepin menggunakan pakaian silat, yaitu celana komprang dan baju lengan panjang hitam, ditambah ikat pinggang dan ikat kepala. Terkadang pementasan kesenian Jepin juga hanya menggunakan pakaian sehari-hari atau pakaian seragam kelompok keseniannya.

\section{B. Eksistensi Kesenian Jepin}

Eksistensi adalah berada atau adanya keberadaan. ${ }^{4}$ Keberadaan kesenian dapat diartikan bahwa kesenian itu ada. Ada disini berarti hadir dan hidup pada masyarakat sesuai dengan kebutuhannya. Keberadaan kesenian ditentukan oleh lingkungan yang membangun kesenian tersebut. Di samping itu, kesenian tidak dapat dilepaskan dengan kehidupan masyarakat pendukungnya, sebab kesenian hidup dan berkembang sesuai dengan perkembangan masyarakat.

${ }^{4}$ Tim Penyusun Kamus, 2005, Kamus Besar Bahasa Indonesia, Balai Pustaka, Jakarta, 288.
Desa Darmayasa merupakan daerah agraris yang mayoritas penduduknya memiliki mata pencaharian pada sektor pertanian. Terbentuknya kesenian Jepin ini tidak akan pernah lepas dari keberadaan masyarakat di Dusun Bandungan sebagai masyarakat pendukungnya. Keberadaan kesenian di tengah-tengah masyarakat dipengaruhi oleh adat istiadat yang berlaku dalam masyarakat tersebut. Apabila kesenian di suatu masyarakat tidak bertentangan dengan adat istiadat dalam masyarakat tersebut, maka kesenian dapat tumbuh dan berkembang dalam kehidupan masyarakat.

Kesenian yang sejalan dengan adat istiadat serta berguna untuk kepentingankepentingan sosial kemasyarakatan, maka suatu kesenian akan tetap lestari dan eksis ${ }^{5}$. Hal ini juga mempengaruhi eksisnya suatu kesenian di dalam masyarakat, hubungan antar seniman sebagai suatu sistem dalam suatu produk (kesenian) sangat menentukan keberhasilan suatu pertunjukan ${ }^{6}$.

Eksistensi kesenian Jepin Bandungan di desa Darmayasa salah satunya adalah sebagai sarana memupuk rasa kebersamaan, sehingga kelompok kesenian tersebut dijadikan sebagai media silaturahmi antar

\footnotetext{
${ }^{5}$ Sumaryono, 2011, Antropologi Tari, BP ISI Yogyakarta, Yogyakarta, 31.

6 Y. Sumandiyo Hadi, 2012, Seni Pertunjukan dan Masyarakat Penonton, BP ISI Yogyakarta, Yogyakarta, 35.
} 
warga. Masyarakat dusun Bandungan masih memegang sistem sosial seperti gotong royong. Solidaritas yang dimiliki tidak hanya sebatas kepada kegiatan desa. Solidaritas pada masyarakat juga terlihat adanya kerjasama, baik itu masyarakat komunitas seniman maupun masyarakat pada umumnya. Sebagai contoh dalam pembuatan panggung dilakukan secara gotong royong yaitu oleh masyarakat.

Seiring dengan perkembangan zaman, masyarakat dusun Bandungan sudah mengenal media elektronik misal televisi. Televisi merupakan salah satu media hiburan pada saat ini. Media tersebut memberikan informasi dan berbagai tayangan realiti maupun drama, tetapi kesenian Jepin masih sering dipentaskan. Dengan demikian kehadiran kesenian tersebut diharapkan dapat memperkecil frekuensi ketergantungan masyarakat terhadap televisi. Apabila semua hiburan didapatkan dari media hiburan, maka kesadaran akan solidaritas berkurang. Kehadiran kesenian Jepin diharapkan dapat menjadi salah satu alternatif dalam media hiburan.

Kesenian Jepin Bandungan di desa Darmayasa keberadaannya tidak lepas dari faktor kebutuhan masyarakat desa Darmayasa. Eksistensi kesenian Jepin di tengah-tengah kehidupan masyarakat desa Darmayasa adalah sebagai hiburan. Hiburan sebagai salah satu kebutuhan manusia, sangat penting dalam kehidupan manusia. Kebutuhan yang lebih bersifat batiniah ini merupakan kebutuhan hampir setiap umat manusia, termasuk masyarakat dusun Bandungan. Sejak kehadiran kelompok kesenian Jepin Bandungan, cenderung kebutuhan masyarakat terhadap pertunjukan kelompok tersebut meningkat. Peningkatan tersebut terlihat dari setiap acara yang diadakan warga seperti pesta perkawinan, khitanan, atau bersih desa dan lainnya, dihadirkan kesenian Jepin sebagai hiburan. Melalui wahana hiburan seperti ini mereka mendapatkan kesenangan dan kepuasan batin yang dapat diperoleh melalui kesenian.

Kesenian Jepin tetap eksis hingga sekarang terbukti dari banyaknya masyarakat penonton saat pertunjukan dan masih banyaknya tawaran pentas, selain itu ada beberapaa faktor lain yang mempengaruhi masih eksisnya kesenian Jepin hingga sekarang.

Fungsi adalah suatu perbuatan yang bermanfaat dan berguna bagi kehidupan suatu masyarakat, di mana keberadaan sesuatu tersebut mempunyai arti penting dalam kehidupan sosial. ${ }^{7}$ Berpijak pada pendapat di atas, maka menempatkan kesenian Jepin sebagai kesenian yang berguna dan mempunyai arti penting bagi masyarakat pemiliknya. Arti penting kesenian Jepin bagi

${ }^{7}$ Koentjaraningrat. 1984. Kamus Istilah Antropologi, Pusat Pembinaan dan Pengembangan Bahasa Departemen Pendidikan Dan Kebudayaan, Jakarta ,52. 


\section{JOGED}

ISSN: $1858-3989$
Ika Prawita Herawati (EKSISTENSI KESENIAN JEPIN DI DUSUN BANDUNGAN DESA DARMAYASA KECAMATAN PEJAWARAN KABUPATEN BANJARNEGARA) masyarakat dusun Bandungan dapat dilihat dari fungsi kesenian Jepin sebagai sarana hiburan yang menyuguhkan tontonan yang menarik bagi para penikmatnya, di samping itu kesenian Jepin diciptakan oleh masyarakat untuk memenuhi kebutuhan batin mereka yang diwujudkan dalam bentuk seni.

Kesenian Jepin ini dapat dipentaskan dalam acara-acara yang diselenggarakan oleh masyarakat seperti pada upacara-upacara adat serta pada peringatan-peringatan hari besar nasional. Pementasan ini sangat disukai oleh masyarakat setempat baik anak-anak, remaja maupun orang tua. Untuk melihat pementasan ini juga tidak dipungut biaya sehingga dapat dinikmati dengan bebas. Kebutuhan masyarakat akan kesenian tradisional sebagian besar dirasa masih kurang. Memang pada masa modern ini teknologi lebih dominan dan diminati banyak orang, hal ini mempengaruhi juga perkembangan kesenian tradisional terutama untuk generasi penerus.

Kata perkembangan memiliki beberapaa makna dan pengertian. Artian yang pertama adalah penggarapan yang berkaitan dengan upaya mengkreasi atau memperbaharui, sedangkan yang kedua adalah penyebarluasan yang berkaitan dengan kewilayahan dan waktu. ${ }^{8}$ Selain itu, arti perkembangan (development) sering diindikasikan sebagai sesuatu yang

${ }^{8}$ Sumaryono. 2007. Jejak dan Problematika Seni Pertunjukan Kita, Prasista, Yogyakarta, 7. mengalami perubahan baik bersifat pengurangan, penambahan dengan segala bentuk variasi kepada tujuan ke arah peningkatan atau kemajuan (progress) ${ }^{9}$.

Kesenian Jepin juga mengalami beberapaa perkembangan terutama dalam bentuk penyajiannya. Perkembangan dalam hal penyajian kesenian Jepin yaitu dengan mengemas pertunjukan agar lebih menarik dan lebih dikenal masyarakat luas. Seperti pengembangan gerak, dan penambahan alat musik rebana. Perkembangan tersebut merupakan salah satu upaya kreativitas yang dilakukan oleh pendukung kesenian Jepin dan juga untuk mempertahankan eksistensi kesenian Jepin. Perkembangan yang terjadi dalam kesenian ini untuk memenuhi selera masyarakat yang semakin berkembang.

Seni pertunjukan baik tari, musik, teater, dan lain sebagainya selalu berhubungan dengan masyarakat sebagai penonton, karena sebuah seni tidak ada artinya tanpa adanya apresiasi, tanggapan, atau respon dari penonton ${ }^{10}$. Hal ini juga berlaku pada kesenian Jepin di dusun Bandungan. Tanpa adanya masyarakat penonton kesenian Jepin di dusun Bandungan tidak akan bertahan hingga saat ini. Tanggapan masyarakat terhadap

\footnotetext{
${ }^{9}$ Sumandiyo Hadi. 2007. Pasang Surut Pelembagaan Tari Klasik Gaya Yogyakarta, Pustaka, Yogyakarta, 21

${ }^{10}$ Y. Sumandiyo Hadi. 2012. Seni Pertunjukan dan Masyarakat Penonton, BP ISI Yogyakarta, Yogyakarta, p. 1
} 
kesenian Jepin masih cukup tinggi, hal ini mengingat fungsi kesenian Jepin sebagai sarana hiburan dan juga sebagai media nadar bagi masyarakat.

Keberadaan kesenian Jepin merupakan bagian dari masyarakat Bandungan yang perlu dilestarikan. Kesenian rakyat yang menjadi bagian dari budaya menempati kedudukan yang baik di mata masyarakatnya. Pertunjukan kesenian Jepin yang sejalan dengan adat istiadat setempat mendapat respon yang baik dari masyarakat. Pertunjukan kesenian Jepin terkadang memberikan keuntungan bagi seniman pendukungnya. Hal tersebut terjadi ketika kesenian Jepin ditanggap. Uang yang Apabila diberikan penanggap masih lumayan banyak tersisa, maka sisa uang tersebut sebagian dimasukkan ke dalam kas paguyuban dan sebagian dibagi kepada seniman kesenian Jepin. Keputusan pembagian uang tanggapan terlebih dahulu melalui musyawarah, karena paguyuban kesenian Jepin ini berazaskan kekeluargaan.

Pada saat pertunjukan, banyak pedagang yang datang ke tempat pertunjukan kesenian Jepin. Keuntungan dari pertunjukan kesenian ini juga dirasakan oleh para pedagang yang datang untuk berjualan di sekitar tempat pertunjukan. Banyaknya penonton kesenian Jepin mempengaruhi penghasilan dari pedagang. Mereka mempunyai penghasilan tambahan dengan adanya pertunjukan kesenian tersebut. Selain itu kesenian Jepin mampu menghibur masyarakat Dusun Bandungan dalam menunggu waktu panen, karena sebagian besar masyarakat bemata pencaharian sebagai petani.

Pada saat pertunjukan berlangsung, masyarakat dusun Bandungan sangat antusias untuk menonton pertunjukan kesenian Jepin. Pertunjukan kesenian ini pada umumnya berlangsung sampai sore hari. Penonton terdiri dari segala kalangan termasuk anak kecil hingga orang tua, tetap menyaksikan pertunjukan hingga selesai ${ }^{11}$. Hal trsebut terjadi karena kesenangan masyarakat dusun Bandungan terhadap pertunjukan kesenian Jepin.

Berdasarkan penjelasan di atas, maka keberadaan kesenian ini perlu dipertahankan karena kesenian Jepin sebagai bagian dari budaya masyarakat dusun Bandungan memberikan manfaat yang baik atau positif bagi masyarakat pada umumnya dan masyarakat pendukung kesenian yaitu masyarakat seniman di paguyuban Jepin Bandungan. Masyarakat sangat mendukung kesenian Jepin. Kesenian Jepin dari awal terbentuknya sampai sekarang. Teknologi yang semakin berkembang yang sudah mempunyai aplikasi untuk melihat berbagai

11 Wawancara dengan Dariah selaku masyarakat dusun Bandungan pada tanggal 21 November 2016 diperbolehkan untuk dikutip 


\section{JOGED}

ISSN: $1858-3989$
Ika Prawita Herawati (EKSISTENSI KESENIAN JEPIN DI DUSUN BANDUNGAN DESA DARMAYASA KECAMATAN PEJAWARAN KABUPATEN BANJARNEGARA) hiburan di dalamnya, media elektronik lain seperti televisi dan hiburan dari internet yang merupakan salah satu faktor penyebab minat masyarakat terhadap kesenian tradisi sedikit berkurang. Hal tersebut tidak terlalu berdampak besar bagi eksistensi keseniaan Jepin terbukti setiap kesenian ini dipertunjukkan masyarakat penonton tetap banyak yang berdatangan untuk menyaksikan kesenian Jepin.

Eksistensi suatu kesenian dapat dilihat dari berapa besar respon masyarakat dalam mendukung kesenian tersebut, tetapi dalam masyarakat tidak semua memberi respon positif terhadap suatu kesenian adapula yang tidak mendukung kesenian tersebut. Tetapi eksistensi bisa terjadi apabila masyarakat pendukung lebih besar dari pada masyarakat yang tidak mendukung jalannya suatu kesenian. Hal itu juga terjadi dalam masyarakat desa Darmayasa tepatnya dusun Bandungan dalam mendukung kesenian Jepin. Di samping respon masyarakat yang antusias terhadap kesenian Jepin ada pula warga yang mengkritik tentang kegiatan kesenian ini salah satunya pada saat diadakannya latihan rutin. Latihan biasanya diselenggarakan pada sore hari atau menjelang ashar. Seniman pendukung kesenian Jepin yang termasuk penari terdiri dari pelajar sampai orang tua.
Beberapa masyarakat salah satunya Suprapti berpendapat bahwa latihan yang diselenggarakan pada sore hari dan bukan akhir pekan akan mengganggu waktu istirahat bagi yang bekerja ataupun pelajar yang baru pulang sekolah yang ikut menjadi penari dalam kesenian tersebut, selain itu waktu dilaksanakannya latihan bertepatan pada waktu ashar, hal itu dapat mengganggu orang yang sedang beribadah, mengingat sebagian besar masyarakat dusun Bandungan beragama Islam $^{12}$.

Hal tersebut adalah beberapaa tanggapan masyarakat dusun Bandungan terhadap kesenian Jepin, banyak masyarakat yang mendukung tetapi ada juga masyarakat yang tidak terlalu mendukung kesenian tersebut, akan tetapi eksistensi kesenian Jepin Bandungan masih eksis sampai sekarang terlihat dari masyarakat pendukung yang lebih banyak dari pada yang tidak mendukung.

\section{PENUTUP}

Kesenian Jepin merupakan salah satu kesenian rakyat tradisional yang berada di dusun Bandungan, desa Darmayasa, kecamatan Pejawaran, kabupaten Banjarnegara. Keberadaan kesenian Jepin di lingkungan masyarakat dusun Bandungan sudah cukup lama. Tumbuh dan

${ }^{12}$ Wawancara dengan Suprapti selaku masyarakat dusun Bandungan pada tanggal 21 November 2016 diperbolehkan untuk dikutip. 
berkembangnya kesenian tersebut sangat dipengaruhi oleh masyarakat pendukungnya yaitu masyarakat dusun Bandungan.

Kesenian Jepin berfungsi sebagai hiburan dalam acara-acara tertentu seperti slamatan, sunatan, peringatan hari kemerdekaan Republik Indonesia dan penyambutan tamu. Kesenian Jepin dipertunjukan dalam berbagai acara dengan tujuan untuk meramaikan acara tersebut. Keberadaan kesenian ini di dusun Bandungan yaitu sebagai sarana memupuk rasa kebersamaan antar warga, mempererat silaturahmi dan pengikat solidaritas masyarakat di dusun tersebut. Rasa memiliki dan bangga terhadap kesenian Jepin ini timbul dari rasa solidaritas yang disadari oleh setiap seniman kesenian tersebut.

Adanya kesenian Jepin memberikan manfaat bagi masyarakat pada umumnya dan masyarakat pendukung kesenian. Tanggapan yang baik dari masyarakat ditunjukan pula dengan semakin menyebar luasnya kesenian Jepin di daerah-daerah bahkan di luar kecamatan Pejawaran. Kesenian Jepin masih bertahan dari awal terbentuknya sampai sekarang dan tetap diminati masyarakat serta eksis tidak terlepas dari masyarakat pendukungnya. Masyarakat pendukung kesenian Jepin terdiri dari seniman kesenian Jepin dan masyarakat penonton dan penyelenggara. Sebuah bentuk seni pertunjukan tidak pernah lepas dari kehidupan seniman yang berperan aktif sebagai penggerak.

Seniman kesenian Jepin berperan dalam melakukan perkembangan yang disesuaikan dengan selera masyarakat. Perkembangan dalam hal penyajian kesenian Jepin yaitu dengan mengemas pertunjukan agar lebih menarik dan lebih dikenal masyarakat luas. Seperti pengembangan gerak, dan penambahan alat musik rebana merupakan upaya-upaya yang dilakukan paguyuban kesenian ini, untuk meningkatkan kreativitas kesenian Jepin demi pengembangan dan pelestarian kesenian tersebut agar tetap eksis.

Pada masyarakat penonton dan penyelenggara, merupakan hal yang paling mendukung eksistensi kesenian Jepin. Kesenian Jepin masih tetap eksis sampai sekarang karena masih banyaknya minat penonton, dan banyaknya frekuensi pementasan atau banyaknya tawaran pentas. Masyarakat penyelenggara juga tidak hanya sebatas masyarakat dusun Bandungan ataupun masyarakat desa Darmayasa saja, akan tetapi telah merambah ke desa-desa lainnya.

Keberadaan masyarakat seniman, masyarakat penonton dan penyelenggara tidak dapat dipisahkan karena adanya faktor saling mendukung. Masyarakat seniman, penonton 


\section{JOGED}

ISSN: $1858-3989$
Ika Prawita Herawati (EKSISTENSI KESENIAN JEPIN DI DUSUN BANDUNGAN DESA DARMAYASA KECAMATAN PEJAWARAN KABUPATEN BANJARNEGARA) dan penyelenggara sama-sama mendukung

eksistensi kesenian Jepin dalam kehidupan masyarakat.

Bertahannya kesenian tersebut menandakan bahwa kesenian Jepin masih mempunyai tempat dalam masyarakat, terutama kaitannya sebagai syarat dalam upacara slamatan khususnya pesta nadar, dan hiburan dalam acara hajatan, dan peringatan hari kemerdekaan Indonesia. Kesenian Jepin tetap bertahan dan diminati oleh masyarakat serta eksis juga karena kesenian ini sejalan dengan adat-istiadat yang berlaku dalam masyarakat dusun Bandungan.

\section{DAFTAR SUMBER ACUAN}

\section{A. Sumber Tercetak}

Hadi, Y.Sumandiyo. 2005. Sosiologi Tari.Yogyakarta: Pustaka.

. 2012. Koreografi Bentuk-Tehnik-Isi. Yogyakarta: Cipta Media

. 2012. Seni Pertunjukan dan Masyarakat Penonton.Yogyakarta: BP ISI Yogyakarta.

Koentjaraningrat. 1985. Pengantar Ilmu Antropologi. Jakarta: Aksara Baru.

Nuraini, Indah, 2011, Tata Rias Dan Busana Wayang Orang Gaya Surakarta, Yogyakarta : BP ISI Yogyakarta.

Pusat Bahasa Departemen Pendidikan Nasional. 2005. Kamus Besar Bahasa Indonesia Edisi Ketiga. Jakarta: Balai Pustaka.

Sumaryono. 2007. Jejak dan Problematika Seni Pertunjukan Kita, Prasista, Yogyakarta,

\section{B. Nara Sumber}

$\begin{array}{ll}\text { Nama } & : \text { Warno } \\ \text { Umur } & : 60 \text { tahun } \\ \text { Jabatan } & : \text { Ketua Paguyuban Jepin Dusun } \\ \text { Bedungan } & \end{array}$

$\begin{array}{ll}\text { Nama } & : \text { Mukhodin } \\ \text { Umur } & : 40 \text { tahun } \\ \text { Jabatan } & : \text { penari kesenian Jepin }\end{array}$

\section{Webtografi}

http://budparbanjarnegara.com/tari-jepin/ 
Ika Prawita Herawati (EKSISTENSI KESENIAN JEPIN DI DUSUN BANDUNGAN

JOGED

DESA DARMAYASA KECAMATAN PEJAWARAN KABUPATEN BANJARNEGARA)

ISSN: $1858-3989$ 